\title{
Innovation and Trade with Heterogeneous Firms
}

\author{
Ngo Van Long \\ Horst Raff \\ Frank Stähler
}

\author{
CESIFO WORKING PAPER NO. 2796 \\ CATEgory 8: TRAde Policy \\ SEPTEMBER 2009
}
An electronic version of the paper may be downloaded
- from the SSRN website: Www.SSRN.com
- from the RePEc website: Www.RePEc.org
- from the CESifo website: www.CESifo-group.org/wp




\title{
Innovation and Trade with Heterogeneous Firms
}

\begin{abstract}
This paper examines how trade liberalization affects the innovation incentives of firms, and what this implies for industry productivity. For this purpose we develop a reciprocal dumping model of international trade with heterogeneous firms and endogenous R\&D. Among the robust results that hold both in the short run when there is no entry, and in the long run under free entry are that trade liberalization increases (decreases) aggregate $R \& D$ for low (high) trade costs and increases expected industry productivity. The central results of the paper regarding firm and industry level R\&D spending differ significantly from the case of homogeneous firms.
\end{abstract}

JEL Code: F12, F15.

Keywords: international trade, firm heterogeneity, R\&D, productivity, market structure.

Ngo Van Long

Department of Economics

McGill University

Canada - Montreal H3A 2T7

ngo.long@mcgill.ca

\author{
Horst Raff \\ Department of Economics \\ University of Kiel \\ Wilhelm-Seelig-Platz 1 \\ Germany - 24098 Kiel \\ raff@econ-theory.uni-kiel.de
}

\author{
Frank Stähler \\ Department of Economics \\ University of Würzburg \\ Sanderring 2 \\ Germany - 97070 Würzburg \\ frank.staehler@uni-wuerzburg.de
}

September 2009

We would like to thank Jonathan Eaton, Andreas Hauer, Ferdinand Mittermaier, Julien Prat, Nicolas Schmitt and participants at the Asian-Pacific Trade Seminar, Asian-Pacific Econometric Society Meeting, ERWIT, CESifo Venice Summer Institute, the Midwest International Economics Meetings, the German Economic Association and seminar audiences for helpful comments and suggestions. 


\section{Introduction}

This paper examines how trade liberalization affects the incentives of firms to innovate. Specifically we study how a reduction in trade barriers affects firms' investment in process $\mathrm{R} \& \mathrm{D}$, and what this implies for industry productivity. Process R\&D refers to investment designed to reduce production costs, thereby making the firm more productive. A key feature of process $R \& D$ is that its outcome is stochastic. Higher R\&D spending only raises the likelihood that the firm will realize a higher level of productivity. However, it is the realized level of productivity that determines the firm's performance, including its domestic sales, export sales and profitability. Only productive firms will be able to survive in the market-place, and only the most productive will be able to bear the cost of exporting. Hence the type of R\&D decision we focus on is one where firms choose their investment level with a view to boosting their chance of success in both domestic and export markets.

Innovation incentives depend on such factors as market size, toughness of existing competition, and the potential for entry and exit of competitors. ${ }^{1}$ Trade liberalization affects all of these factors simultaneously. Firms face tougher import competition at home and may lose market share to imports, which tends to reduce the benefit of undertaking R\&D. On the other hand, they gain easier access to export markets and hence may gain market share abroad. This may lead firms to raise their R\&D spending. Trade liberalization may also affect market structure, thus changing the number not only of foreign but also of domestic competitors. Obviously, then, trade liberalization has non-trivial effects on R\&D incentives. Disentangling these effects is the first task of the paper.

Changes in R\&D investment represent a direct channel through which trade liberalization affects industry productivity. Another is the selection of firms into domestic and export markets. ${ }^{2}$ By this we mean that trade liber-

\footnotetext{
${ }^{1}$ See, for example, the seminal paper by Dasgupta and Stiglitz (1980), as well as the more recent work by Aghion et al. (2004, 2005).

${ }^{2}$ The selection effect is a feature of heterogeneous firm models, such as Melitz (2003).
} 
alization may force the least efficient firms to exit the market, but provides export opportunities to firms that previously found exporting too costly. However, since R\&D investment as well as domestic and export market participation are endogenous, and since all of these decisions are directly affected by trade liberalization, the direct effect of $R \& D$ and the selection effect will interact to determine industry productivity and social welfare. Examining this interaction is the second task.

The current paper makes progress on both tasks by providing a very simple international trade model in which these effects of trade liberalization can be studied. Our model is a variant of the reciprocal dumping model (Brander, 1981; Brander and Krugman, 1983), in which firms are ex post heterogeneous a la Melitz (2003). Firms decide on entry and their R\&D spending before observing their marginal cost. R\&D simply shifts the cost distribution. Firms then individually learn their marginal cost, and finally play a Bayesian Cournot game determining their domestic and foreign sales. The model allows us to derive the comparative static effects of a reduction in trade costs on R\&D, domestic output, and exports at the firm level. It also lets us determine how trade liberalization affects the cut-off levels of firm productivity that separate firms that are not able to sell any output from the more productive ones that serve the domestic market, and the latter from the most productive ones that also export. From the changes in firm-level decisions and the selection effects induced by changes in the cut-off values we can then compute how trade liberalization affects aggregate industry productivity.

This novel approach of modelling firm heterogeneity in an oligopolistic market rather than in monopolistic competition has an important benefitin addition to its simplicity. In particular, it explicitly reproduces output and mark-up adjustments by firms, which are among the most robust empirical regularities of trade liberalization (see Tybout (2003) and Wagner (2007)). ${ }^{3}$

Both adjustment channels are empirically important. See Lileeva and Trefler (2007), Greenaway and Kneller (2007), and Wagner (2007) for recent surveys of the literature.

${ }^{3}$ Output and mark-up effects are typically absent in monopolistic competition models. See Melitz and Ottaviano (2008) for an exception. 
We are able to derive sufficient conditions under which trade liberalization reduces the price-cost margins and domestic sales of import-competing firms, expands export markets for very efficient firms, and increases efficiency at the plant level. In our setup, plant level efficiency is endogenous as firms directly adjust their R\&D in response to the risks and opportunities associated with economic integration.

We examine the effects of trade liberalization in two scenarios, a shortrun scenario in which there is no entry, and a long-run scenario in which free entry and exit of firms determines the market structure. We are especially interested in identifying trade liberalization effects that are robust in that they hold across different market structures and can therefore be expected to occur across a wide range of industries irrespective of the time frame and of (often unobserved) sector-specific entry and exit costs. Among other things, we show, that trade liberalization (i) raises (reduces) aggregate $R \& D$ spending when trade costs are low (high); and (ii) forces firms at the bottom of the productivity distribution to produce zero expected output. The two effects determining how industry productivity reacts to trade liberalization may hence go in the same or in opposite directions. In particular, the direct effect coming from changes in R\&D counteracts (reinforces) the selection effect when trade costs are high (low). However, we are able to prove that the selection effect dominates so that expected industry productivity rises unambiguously as trade costs fall.

Firm heterogeneity plays a crucial role in obtaining these results. This, of course, is obvious when it comes to the selection effect, which does not exist when firms are homogeneous. Surprisingly, however, it is firm heterogeneity that drives the non-monotonicity in the effect of trade liberalization on aggregate R\&D spending. When firms are homogeneous, trade liberalization can be shown to unambiguously raise industry-level R\&D spending.

Our paper is most closely related to the recent work of Costantini and Melitz (2008), and Atkeson and Burstein (2006) who also examine innovation and export decisions in a model with heterogeneous firms. Both papers 
start from a situation in which firms already differ in their initial productivity before an innovation opportunity arises (a binary choice in the former, a continuous choice in the latter paper), and then study how productivity differences evolve over time when trade costs fall. The former paper examines the transition dynamics between two steady states, and finds that productivity effects depend on whether liberalization is anticipated and on how quickly it is implemented. The latter paper studies the long-run dynamics. It shows that a reduction in trade costs induces more (less) productive firms to spend more (less) on innovation, thus becoming even more (less) productive over time. ${ }^{4}$

By contrast, firms in our model decide on innovation investment before they know their productivity. This assumption allows us to isolate the innovation- and selection-induced changes in productivity from effects generated by initial conditions. Furthermore, in our model of oligopolistic competition, firms choose their $\mathrm{R} \& \mathrm{D}$ level while taking into account the risks of facing tougher competition triggered by trade liberalization. Tougher competition affects their R\&D choice directly, and not only via the price index as in standard monopolistic competition models, and this is the reason why we find that $R \& D$ spending is non-monotonic in trade costs. The simplicity of our model has the added advantage that we are able to perform classic comparative static analysis, which makes the economics behind these changes very transparent. Costantini and Melitz, and Atkeson and Burstein, on the other hand, have to rely on numerical simulation for most of their results. ${ }^{5}$

Other related papers include Bustos (2007) and Navas and Sala (2007) who study technology adoption in the Melitz model and show that trade liberalization raises the incentive of exporters to adopt a more advanced technology. Gustafson and Segerstrom (2006) also introduce innovation into

\footnotetext{
${ }^{4}$ A similar effect is discussed in Aghion and Griffith (2005), ch. 4.

${ }^{5}$ Other related papers include Ederington and McCalman (2008) and Yeaple (2005) who examine the effect of trade liberalization on technology adoption. The adoption process also leads to ex-post differences in firm productivity. Haaland and Kind (2008) employ a model in which R\&D and exports are determined simultaneously, but their focus is on the effect of $R \& D$ subsidies.
} 
the Melitz (2003) model; R\&D in their model is carried out in an innovation sector and depends crucially on the presence of intertemporal knowledge spillovers in the innovation sector. ${ }^{6}$ Vannoorenberghe (2008) studies process innovation in the Melitz model; he finds that larger exporters invest more in innovation, and firms entering export markets raise their R\&D spending.

The remainder of the paper is structured as follows. Section 2 introduces the model. In Section 3 we investigate the effects of trade liberalization under the assumption that firms are homogenous. This provides a useful benchmark to evaluate the impact of firm heterogeneity. The core of the paper is in Section 4, which contains the results for the case of heterogeneous firms. Section 5 concludes, and the Appendix contains proofs.

\section{The Model}

We consider a reciprocal dumping model of trade with two segmented markets: the home and the foreign market. Firms in the two markets produce a homogeneous good and engage in Cournot competition. Consumers in each market have quadratic quasi-linear preferences that give rise to a linear inverse demand function,

$$
p_{j}=A-Q_{j},
$$

where $p_{j}$ and $Q_{j}$ denote price and total sales in market $j$. Labor is the only factor of production and comes in fixed supply. Assuming that the numeraire good is produced under constant returns to scale at unit cost and traded freely on a competitive world market, the equilibrium wage in each country is equal to one, and trade is always balanced.

The per-unit trade cost on shipments between countries is denoted by $t$. We treat $t$ as a resource cost, such as the cost of transporting goods or overcoming non-tariff barriers. Trade liberalization is modelled as a marginal fall in $t$ in both countries.

\footnotetext{
${ }^{6}$ See also Baldwin and Robert-Nicoud (2008) for a model of how trade affects innovation and growth when firms are heterogeneous.
} 
Let $n$ denote the number of entrants in each market. Firms produce under constant (but ex-ante unknown) marginal cost, equal to the unit labor requirement. We assume that the marginal cost of firm $i=1, \ldots, n$, denoted by $c_{i}$, is revealed to the firm only after it has incurred a sunk set-up cost $f>0$ and invested an amount $r_{i} \geq 0$ in R\&D. By conducting R\&D a firm increases its chances to become a lower-cost firm. The probability that firm $i$ 's marginal cost is less than or equal to $c_{i}$ is given by $G\left(c_{i}\right)$, where

$$
G\left(c_{i}\right)=g\left(r_{i}\right) F\left(c_{i}\right), g(0)=1, g^{\prime}>0, g^{\prime \prime} \leq 0 .
$$

The ex-ante cumulative distribution $F\left(c_{i}\right)$ has support on the interval $[0, \bar{c}]$. Obviously, expression (2) is defined only as long as $G\left(c_{i}\right) \leq 1 .^{7}$ The cost of $\mathrm{R} \& \mathrm{D}$ is given by

$$
\rho\left(r_{i}\right): \rho(0)=0, \rho^{\prime}>0, \rho^{\prime \prime} \geq 0 .
$$

We assume that both the level of $R \& D$ and the marginal-cost realization are private information of each firm. Hence output decisions are made under asymmetric information, and the R\&D investment has no effect on the output choice of rival firms. ${ }^{8}$ Upon learning its marginal cost, firm $i$ will produce a quantity $y\left(c_{i}\right)$ for the domestic market and $x\left(c_{i}\right)$ for the export market. This output decision will depend on the expected output of all rival firms in the domestic market, denoted by $\widehat{Q}_{-i} \cdot{ }^{9}$ Firm $i$ 's first-order condition for its domestic sales $y_{i}\left(c_{i}\right)$ is

$$
p\left(y_{i}\left(c_{i}\right)+\widehat{Q}_{-i}\right)+y_{i}\left(c_{i}\right) p^{\prime}\left(y_{i}\left(c_{i}\right)+\widehat{Q}_{-i}\right)-c_{i} \leq 0,\left(=0 \text { if } y_{i}\left(c_{i}\right)>0\right) .
$$

From (4), we may derive the critical marginal cost, $\widetilde{c}_{y_{i}} \equiv A-\widehat{Q}_{-i}$, for which firm $i$ 's domestic sales become zero. Then the first-order conditions

${ }^{7}$ Precisely, $G\left(c_{i}\right)=\min \left(g\left(r_{i}\right) F\left(c_{i}\right), 1\right)$.

${ }^{8} \mathrm{An}$ increase in R\&D therefore cannot serve as a commitment device to be more aggressive in both markets. This is similar to the model of Haaland and Kind (2008) which assumes that outputs and R\&D are determined simultaneously by each firm.

${ }^{9}$ That is, firms have to take expectations even after entry, since the (unobserved) marginal cost draws of their rivals determine these rivals' output choices and thus residual demand in the domestic and foreign markets. 
give rise to the decision rule ${ }^{10}$

$$
y_{i}\left(c_{i}\right)=\left\{\begin{array}{cl}
0 & \text { if } c_{i} \geq \widetilde{c}_{y_{i}}, \\
\frac{1}{2}\left(\widetilde{c}_{y_{i}}-c_{i}\right) & \text { if } c_{i}<\widetilde{c}_{y_{i}} .
\end{array}\right.
$$

Since in the current model a firm's mark-up is the same as its output, the ex-post profit in the domestic market is equal to

$$
\pi_{i}\left(c_{i}\right)=\left\{\begin{array}{cl}
0 & \text { if } c_{i} \geq \widetilde{c}_{y_{i}}, \\
\frac{1}{4}\left(\widetilde{c}_{y_{i}}-c_{i}\right)^{2} & \text { if } c_{i}<\widetilde{c}_{y_{i}} .
\end{array}\right.
$$

Similarly, let $\widehat{Q}_{-i}^{*}$ denote the expected output of all rivals in the export market. Firm $i$ 's first-order condition for its exports $x_{i}\left(c_{i}\right)$ is

$$
p\left(x_{i}\left(c_{i}\right)+\widehat{Q}_{-i}^{*}\right)+x_{i}\left(c_{i}\right) p^{\prime}\left(x_{i}\left(c_{i}\right)+\widehat{Q}_{-i}^{*}\right)-t-c_{i} \leq 0,\left(=0 \text { if } x_{i}\left(c_{i}\right)>0\right),
$$

and the critical marginal cost for which its exports become zero is $\widetilde{c}_{x_{i}} \equiv$ $A-\widehat{Q}_{-i}^{*}-t$. Hence the quantity of exports is

$$
x_{i}\left(c_{i}\right)=\left\{\begin{array}{cl}
0 & \text { if } c_{i} \geq \widetilde{c}_{x_{i}}, \\
\frac{1}{2}\left(\widetilde{c}_{x_{i}}-c_{i}\right) & \text { if } c_{i}<\widetilde{c}_{x_{i}},
\end{array}\right.
$$

and the ex-post export profit is

$$
\pi_{i}^{*}\left(c_{i}\right)=\left\{\begin{array}{cl}
0 & \text { if } c_{i} \geq \widetilde{c}_{x_{i}} \\
\frac{1}{4}\left(\widetilde{c}_{x_{i}}-c_{i}\right)^{2} & \text { if } c_{i}<\widetilde{c}_{x_{i}}
\end{array}\right.
$$

Using (6) and (9) we may write the total expected profit of firm $i$ as

$$
\Pi_{i}\left(r_{i}\right)=\frac{g\left(r_{i}\right)}{4} \Omega_{i}-\left(f+\rho\left(r_{i}\right)\right)
$$

where

$$
\Omega_{i} \equiv \int_{0}^{\widetilde{c}_{y_{i}}}\left(\widetilde{c}_{y_{i}}-c_{i}\right)^{2} d F\left(c_{i}\right)+\int_{0}^{\widetilde{c}_{x_{i}}}\left(\widetilde{c}_{x_{i}}-c_{i}\right)^{2} d F\left(c_{i}\right) .
$$

Each entrant chooses its R\&D level according to the following first-order condition:

$$
\frac{\partial \Pi_{i}}{\partial r_{i}}=g^{\prime}\left(r_{i}\right) \frac{\Omega_{i}}{4}-\rho^{\prime}\left(r_{i}\right)=0 .
$$

\footnotetext{
${ }^{10}$ See also Cramton and Palfrey (1990), Lemma 5 (p. 26 and pp. 41-2).
} 
Since firms are identical prior to learning their cost realization, equilibrium R\&D spending will be the same for all entering firms. For future convenience, let us denote the symmetric equilibrium level of $\mathrm{R} \& \mathrm{D}$ by $\widehat{r}$, where

$$
g^{\prime}(\widehat{r}) \Omega-4 \rho^{\prime}(\widehat{r})=0 .
$$

The following assumption guarantees that $\widehat{r}>0$ :

\section{Assumption 1}

$$
\Omega>4 \rho^{\prime}(0)
$$

Since all entrants choose the same R\&D level, the expected outputs of firms will coincide in equilibrium. Furthermore, since the two countries are identical, the expected domestic and export sales of home firms will be identical to those of foreign firms. In its local market firm $i$ will face $n-1$ domestic rivals, each expected to produce and sell $\widehat{y}$ units, and $n$ rivals from abroad, each expected to sell $\widehat{x}$ units; hence, $\widehat{Q}_{-i}=(n-1) \widehat{y}+n \widehat{x}$. Similarly in its export market, the firm competes with $n-1$ other exporters and $n$ local firms so that $\widehat{Q}_{-i}^{*}=n \widehat{y}+(n-1) \widehat{x}$. The critical values of the marginal cost can thus be written as

$$
\begin{aligned}
\widetilde{c}_{y} & =A-(n-1) \widehat{y}-n \widehat{x}, \\
\widetilde{c}_{x} & =A-(n-1) \widehat{x}-n \widehat{y}-t .
\end{aligned}
$$

Using symmetry, the following Lemma shows that the expected local and export sales of a firm are determined by a system of only two equations:

Lemma 1 Expected sales are

$$
\begin{aligned}
& \widehat{y}=\frac{g(\widehat{r})}{2} \int_{0}^{\widetilde{c}_{y}} F(c) d c, \\
& \widehat{x}=\frac{g(\widehat{r})}{2} \int_{0}^{\widetilde{c}_{x}} F(c) d c .
\end{aligned}
$$


Proof: See Appendix A.1.

We may also use symmetry to rewrite the expected equilibrium profit of a firm as follows

$$
\widehat{\Pi}=\frac{g(\widehat{r})}{4} \Omega-(f+\rho(\widehat{r}))
$$

where

$$
\begin{aligned}
\Omega \equiv & \int_{0}^{\widetilde{c}_{y}}[A-(n-1) \widehat{y}-n \widehat{x}-c]^{2} d F(c)+ \\
& \int_{0}^{\widetilde{c}_{x}}[A-(n-1) \widehat{x}-n \widehat{y}-t-c]^{2} d F(c) .
\end{aligned}
$$

In our analysis below we will refer to the effect of trade liberalization on firm and industry productivity. We follow Melitz (2003) in defining firm productivity as the inverse of the marginal production cost, and industry productivity as the inverse of the expected marginal cost, conditional on firms producing positive output. This conditional expectation is given by

$$
E\left(c \mid c \leq \widetilde{c}_{y}\right)=\frac{1}{G\left(\widetilde{c}_{y}\right)} \int_{0}^{\widetilde{c}_{y}} c d G .
$$

Next we examine how trade liberalization in the form of a marginal reduction in $t$ affects the equilibrium of the model. We first consider the case of homogeneous firms. This provides a benchmark against which we can compare the effect of firm heterogeneity. We then turn to the full model and show what difference firm heterogeneity makes.

\section{Trade Liberalization with Homogeneous Firms}

Firm homogeneity means that all incumbent firms and all potential entrants have the same marginal cost function. There is hence no private information, and the model is formally equivalent to one in which firms, after deciding on entry and exit, simultaneously choose R\&D, domestic output and export sales; the key point is that the $R \& D$ investment does not play a strategic role in the output choice. 
It is natural to let R\&D directly impact the marginal cost of production. Hence writing marginal cost as $c(r),{ }^{11}$ with $c^{\prime}<0$, the profit of a home firm is equal to $(A-Q-c(r)) y+\left(A-Q^{*}-c(r)-t\right) x-\rho(r)$, and the first-order conditions of profit maximization with respect to $y, x$ and $r$, respectively, are given by

$$
\begin{gathered}
A-Q_{-i}-2 y-c=0, \\
A-Q_{-i}^{*}-2 x-c-t=0, \\
-c^{\prime}(x+y)-\rho^{\prime}=0 .
\end{gathered}
$$

Defining $\Delta \equiv-c^{\prime \prime}(x+y)-\rho^{\prime \prime}<0$, and assuming that $\Delta+c^{\prime 2}<0$, it is straightforward to show that the second-order conditions are satisfied. ${ }^{12}$ Free entry and exit of firms implies the following zero-profit condition for a home firm:

$$
(A-Q-c) y+\left(A-Q^{*}-c-t\right) x-\rho-f=0 .
$$

If $R \& D$ is excluded, the model is essentially identical to the original Brander (1981) model. The introduction of R\&D into the model leaves the effects of trade liberalization on a firm's domestic and export sales as well as on the number of firms qualitatively unchanged. The impact of trade liberalization on R\&D spending by a firm is unambiguously positive, whether or not there is free entry. In particular, we can show:

Proposition 1 If firms are homogeneous, trade liberalization (i) raises a firm's exports and reduces its domestic sales, (ii) increases the firm's overall sales, (iii) raises the firm's REDD spending, and (iv) raises industry productivity. These results hold both with and without free entry. In addition, (v) if there is free entry, trade liberalization raises the number of firms.

Proof: see Appendix A.2.

The intuition for these effects is straightforward. Trade liberalization exposes firms to tougher import competition, forcing them to reduce domestic sales.

\footnotetext{
${ }^{11}$ Our model is equivalent to the last section's model except that costs depend on R\&D deterministically, and thus firms do not select themselves in equilibrium.

${ }^{12}$ See Appendix A.2 for details.
} 
But it also allows them to expand their exports. The increase in export sales exceeds the fall in domestic sales. This expansion in firm output raises the marginal benefit of undertaking cost-reducing R\&D. ${ }^{13}$ The expansion in firm output and the rise in R\&D spending both imply higher profits, which induces entry. The increase in $R \& D$ spending reduces the marginal cost and thus raises productivity both at the firm and the industry level; we will refer to this as the direct effect of trade liberalization.

Since R\&D has no strategic effect, firms completely internalize the costs and benefits of $R \& D$. That is, firms raise their $R \& D$ because it increases their profit relative to the case where $R \& D$ spending is held fixed. This implies that social welfare is higher than in the Brander model, which corresponds to the case where R\&D spending is fixed at zero. Qualitatively, however, trade liberalization has the same welfare effects as in the Brander model. Specifically, we prove in Appendix A.5 that when the number of firms is fixed, the welfare effect of trade liberalization is non-monotonic. Sufficiently close to autarky, a marginal reduction in trade costs reduces welfare. Close enough to free trade, it raises social welfare. ${ }^{14}$ When the market structure is endogenous, social welfare is equal to consumer surplus. Since trade liberalization raises both the output per firm and the total number of firms, industry output and thus consumer surplus rise unambiguously. ${ }^{15}$

\footnotetext{
${ }^{13}$ A similar effect is also found by Licandro and Navas-Ruiz (2008) who go on to investigate the consequences for economic growth.

${ }^{14}$ In the Brander model welfare in each country is equal to $A Q-Q^{2} / 2-c Q-\operatorname{tnx}$. Differentiating welfare w.r.t. $t$ shows that welfare is convex in $t$ and has a minimum at $t^{\mathrm{min}} \equiv(2(A-c)(n+1)) /(2+n(5+4 n))$. A marginal decrease in $t$ thus reduces welfare if $t$ is between $t^{\mathrm{min}}$ and the prohibitive level, and it increases welfare if $t$ is smaller than $t^{\mathrm{min}}$.

If we treated the trade cost not as a pure resource cost but as a tariff, then tariff revenue would also enter the social welfare function. To see where this matters consider a marginal increase in $t$ starting from $t=0$. This increase generates positive tariff revenue and hence raises welfare. This is the well known result that the optimal tariff in the Brander model is positive.

${ }^{15}$ This is exactly the result shown by Brander and Krugman (1983) in the case without R\&D.
} 


\section{Trade Liberalization with Heterogeneous Firms}

We now examine the impact of trade liberalization when firms are heterogeneous. It turns out to be convenient to separately analyze the case of no entry and the case of an endogenous market structure, because the two differ significantly from each other and from the homogeneous firm case.

\subsection{No-Entry Case}

In the absence of market entry the equilibrium $\widehat{y}, \widehat{x}$ and $\widehat{r}$ are determined by equations (13) - (17). To derive the comparative static effects of a reduction in $t$ we totally differentiate these equilibrium conditions. This yields the following comparative static results:

Proposition 2 If firms are heterogeneous and there is no market entry, trade liberalization (i) increases a firm's expected exports; (ii) decreases its expected local sales when trade costs are high; (iii) increases a firm's expected total output when trade costs are sufficiently low; (iv) increases (decreases) firm-level R\&D when trade costs are low (high); and (v) raises industry productivity.

Proof: see Appendix A.3.

The main difference relative to the case of homogeneous firms is that the effect of trade liberalization on $R \& D$ spending is no longer monotonic. What is more, when the trade cost is high, the effect on $R \& D$ is the exact opposite of the one in the homogeneous firm model: trade liberalization now reduces R\&D. Since trade liberalization raises $R \& D$ spending for low trade costs, it has to be the case that with heterogeneous firms $R \& D$ spending has an interior minimum.

To develop intuition for these results consider the effect of trade liberalization on the threshold values of the marginal cost, $\widetilde{c}_{y}$ and $\widetilde{c}_{x}$. For $t=0$ we obviously have $\widetilde{c}_{y}=\widetilde{c}_{x}$ : there is only one critical value such that firms with 
marginal cost draws below this value are active on the integrated home and foreign markets, whereas firms with higher marginal costs do not produce any output. For $t>0$, we must have $\widetilde{c}_{y}>\widetilde{c}_{x}$. The most efficient firmsthose with cost draws below $\widetilde{c}_{x}$-produce for both the domestic and export markets, firms with cost draws between $\widetilde{c}_{y}$ and $\widetilde{c}_{x}$ sell only on the domestic market; firms with marginal costs above $\widetilde{c}_{y}$ do not sell anything. Moreover, as shown in Appendix A.3, $d \widetilde{c}_{y} / d t>0$ and $d \widetilde{c}_{x} / d t<0$. This implies that as trade costs decline, the threshold cost level $\widetilde{c}_{x}$ rises, so that more firms will now be able to export. On the other hand, the threshold cost level $\widetilde{c}_{y}$ falls, meaning that firms that before were barely efficient enough to sell on their local market are now forced to produce zero output.

Consider first how trade liberalization affects a firm's expected sales holding fixed the level of R\&D expenditure. Expected export sales rise, since trade liberalization raises the probability that any given firm will be efficient enough to be able to export, and allows those firms that do export to increase their shipments abroad. Expected domestic sales decrease, since firms respond to import competition by reducing local sales. In addition, the likelihood that a given firm will be able to sell on its local market falls. These arguments explain the increase in export sales (part (i) of the Proposition) and the fall of domestic sales when trade costs are high. Domestic sales may rise or fall if trade costs are low due to changes in R\&D spending. Specifically, expected domestic sales may even rise after trade liberalization if increased R\&D leads to such a strong shift in the cost distribution such that the expected marginal cost drops substantially. The effect of trade liberalization on total sales of a firm is unambiguously positive (part (iii)) only when trade costs are low, as the expected increase in exports more than compensates even an expected decrease in domestic sales. The effect is ambiguous in the case of high trade costs.

How does R\&D respond to a reduction in the trade cost? A firm selling only on the domestic market would want to reduce its R\&D spending, since tougher competition from imports decreases its output and hence also 
the marginal benefit from $R \& D$. An exporter would want to increase $R \& D$, since the increase in its export sales more than compensates for the decrease in local market share, meaning that it has a greater incentive to invest in cost-reducing $\mathrm{R} \& \mathrm{D}$. This is exactly the same reasoning as in the case of homogeneous firms: With $t$ sufficiently close to zero, a firm's expected export volume is sufficiently large to tip the balance in favor of increasing R\&D in response to a marginal fall in trade cost. Expected domestic sales can even rise if increased $R \& D$ leads to a big enough reduction in expected marginal costs. By contrast, if $t$ is near the prohibitive level, another mechanism takes over: both the expected volume of exports and the probability of being an exporter become very small ( $\widehat{x}$ and $\widetilde{c}_{x}$ are low) relative to the probability of facing import competition on the domestic market. That is, the risks of facing competition by foreign firms are greater than the chances afforded by export opportunities. This implies that for high trade costs, R\&D spending falls as trade is liberalized. This explains the non-monotonic relationship between trade costs and R\&D in part (iv).

Like in the case of homogeneous firms trade liberalization has a direct effect on expected firm productivity due to changes in $\mathrm{R} \& \mathrm{D}$ investment. However, as shown above, the sign of this effect now depends on the size of trade costs. When it comes to industry productivity, firm heterogeneity induces an additional effect that is not present when firms are homogeneous, namely a selection effect. That is, expected industry productivity rises as the least efficient firms are driven to produce zero output. This effect is stronger than the effect of reduced $R \& D$ (in the case of high trade cost), and it ultimately determines how trade liberalization affects expected industry productivity.

The welfare effects of trade liberalization are qualitatively similar to those with homogeneous firms. We show formally in Appendix A.6 that the effect on expected social welfare is positive when trade costs are sufficiently low, and negative when trade costs are near the prohibitive level. Since expected output increases with trade liberalization, it follows that consumer surplus 
must rise. The effect on the domestic firms' expected profits is generally ambiguous. For $t$ sufficiently close to zero the usual pro-competitive effect of trade liberalization dominates, meaning that the increase in consumer surplus caused by tougher competition more than compensates for the decline in expected industry profits. If $t$ is near the prohibitive level, the rise in consumer surplus is outweighed by the fall in the aggregate profits of home firms, because the expected increase in profit on export sales is very small compared with the reduced profit in the domestic market.

\subsection{Endogenous Market Structure}

Now consider the case of an endogenous market structure. Free entry and exit of firms ensures that expected profits (18) are zero, which implies that

$$
\frac{\Omega}{4}=\frac{\rho(r)+f}{g(r)} .
$$

Since $\Omega$ is a function of $r, t$ and $n$, this equation implicitly defines $r$ as a function of $t$ and $n$. Using (25), we may therefore rewrite the first-order condition for R\&D, (12), as:

$$
\frac{g^{\prime}(r(t, n))}{g(r(t, n))}=\frac{\rho^{\prime}(r(t, n))}{\rho(r(t, n))+f} .
$$

Assuming that this equation has a unique positive solution, $r(t, n)=\widehat{r}>0$, we obtain:

Lemma 2 If firms are heterogeneous and market structure is endogenous, firm-level RED is independent of the trade cost.

This means that in a free-entry equilibrium any change in the trade cost leads to an adjustment in the number of firms such that the incentive to undertake R\&D remains unchanged. ${ }^{16}$ We will explain the intuition for this result below.

\footnotetext{
${ }^{16}$ Atkeson and Burstein (2006) and Eaton and Kortum (2001) also feature results that trade liberalization leaves firm-level R\&D unchanged. In both papers a reduction in trade costs, per se, raises the incentive to innovate. In Atkeson and Burstein, however, the wage of managers required for innovation also rises. When all firms export, it rises so much that
} 
For now, it is important to note that this prediction differs fundamentally from the case of homogeneous firms, where trade liberalization leads firms to raise their R\&D spending even under free entry. Also recall that with homogeneous firms trade liberalization raised aggregate $R \& D$ in the industry through two separate effects, namely through the increase in R\&D per firm and through an increase in the number of firms. Lemma 2 implies that in the case of heterogeneous firms any effect of trade liberalization on aggregate R\&D can only come from a change in the equilibrium number of firms. In fact, we will show that the equilibrium number of firms and hence aggregate R\&D spending fall, when the trade cost is sufficiently high.

According to Lemma 2, we may treat $R \& D$ expenditures as a fixed cost and use equations (16), (17) and (25) to solve for the remaining endogenous variables $(n, \widehat{x}, \widehat{y})$. We may rewrite these equations as

$$
\begin{gathered}
2 \widehat{y}-\int_{0}^{A-(n-1) \widehat{y}-n \widehat{x}} G(c) d c=0 \\
2 \widehat{x}-\int_{0}^{A-(n-1) \widehat{x}-n \widehat{y}-t} G(c) d c=0 \\
\int_{0}^{A-(n-1) \widehat{y}-n \widehat{x}}[A-(n-1) \widehat{y}-n \widehat{x}-c]^{2} d G(c)+ \\
\int_{0}^{A-(n-1) \widehat{x}-n \widehat{y}-t}[A-(n-1) \widehat{x}-n \widehat{y}-t-c]^{2} d G(c)-4(f+\rho(\widehat{r}))=0 .
\end{gathered}
$$

Total differentiation of (27), (28) and (29) yields the following comparative static results:

Proposition 3 If firms are heterogeneous and market structure is endogenous, trade liberalization (i) increases a firm's expected exports and decreases its expected local sales; (ii) increases a firm's the expected output if the trade

the innovation effort remains constant. In Eaton and Kortum the offsetting effect comes from the fact that trade liberalization raises the likelihood that a foreign competitor makes an innovation and captures the whole market. 
cost is high; (iii) increases (decreases) the number of firms and hence aggregate RED if the trade cost is low (high); and (iv) raises industry productivity.

Proof: see Appendix A.4.

Trade liberalization has the same effects on the threshold levels of marginal cost as in the fixed market structure case (see Appendix A.4). The impact of trade liberalization on expected domestic and export sales is therefore straightforward: the probability that a given firm exports rises as do sales of each exporting firm abroad. Increased competition from abroad reduces both the probability that a firm remains viable and the local sales of viable firms. Firm heterogeneity drives the result that trade liberalization reduces the number of entrants and raises expected output of each firm when the trade cost is high: like in the no-entry case, trade liberalization increases the risk of facing import competition relative to the chance of benefiting from better access to the export market. Greater expected import competition forces firms to expand output to keep the expected profit at zero. As firms become bigger, the number of entrants has to fall. To understand why we observe a different effect at low trade costs, consider an infinitesimal decrease in the trade cost close to free trade. Such a decrease leaves the expected output of a firm nearly unchanged because the trade cost is already low, but it increases expected profit. Hence at free trade, and by continuity sufficiently close to it, trade liberalization will raise the number of entrants and therefore also industry-level R\&D.

Proposition 3 also helps to explain Lemma 2 and is consistent with Proposition 2 . In the no-entry case trade liberalization leads to an increase in R\&D and higher expected profits when the trade cost is low, but it reduces $R \& D$ spending and expected profits when the trade cost is high. Greater expected profits induce market entry as indicated by Proposition 3, which in turn makes R\&D less profitable. When trade liberalization reduces expected profits, firms exit and the incentive to undertake $R \& D$ rises. Market entry and exit thus counteract the R\&D effects observed in the no-entry case. This suggests that the mechanism that drives Lemma 2 is fairly general, even if 
the result that these effects exactly offset each other so that firm-level R\&D stays constant is specific to our model.

Since R\&D per firm remains constant, trade liberalization affects industry productivity only through the selection effect. By forcing the least efficient firms to leave the market trade liberalization unambiguously raises industry productivity. In the case of homogeneous firms we get the same outcome but for entirely different reasons. Recall that with homogeneous firms the channel through which trade liberalization affects industry productivity consists of an increase in R\&D per firm and in the number of entrants.

Finally consider the effects of trade liberalization on social welfare. Since expected profits are zero due to free entry, the effect of trade liberalization on social welfare is equal to the effect on consumer surplus. As in the case of homogeneous firms, total industry output and hence consumer surplus unambiguously increases with trade liberalization (see Appendix A.6 for a formal proof).

\section{Conclusions}

In this paper we developed a simple model of international trade with heterogeneous firms to explore the effects of trade liberalization on firms' innovation incentives, as well as on industry productivity, and social welfare. We found that the effect on expected industry-level $R \& D$ spending is non-monotonic. That is, trade liberalization raises industry $R \& D$ expenditure when the trade cost is low, and reduces industry $\mathrm{R} \& \mathrm{D}$ expenditure when the trade cost is high. When there is no market entry, this is due to the underlying changes in firms' $R \& D$ investments. In the case of an endogenous market structure, trade liberalization induces changes in the number of firms such that each individual firm has no incentive to alter its R\&D spending. The industry-level R\&D pattern then arises due to the relationship between the trade cost and the number of firms.

The impact of trade liberalization on industry productivity is dominated by the selection effect, by which the least efficient firms are forced to pro- 
duce zero output in the short run and leave the market in the long run. Hence trade liberalization unambiguously leads to higher industry productivity, despite that fact that aggregate $R \& D$ spending may rise or fall. This result is important because the productivity enhancing effect of trade is often portrayed as one of the main reasons why trade liberalization may raise social welfare. When the market structure is endogenous, the higher industry-level productivity indeed translates into higher consumer surplus and social welfare. However, our paper also showed that this may not be true in the short run when there is no entry.

Firm heterogeneity plays a crucial role in obtaining these results. We found that quite a few of the effects derived under firm homogeneity are not robust to the introduction of firm heterogeneity. This is especially true for the effects of trade liberalization on $R \& D$ investment at the firm- and industry-level. In the case of homogeneous firms a marginal reduction in trade costs boosts R\&D spending at the firm and industry level irrespective of whether there is entry or not and irrespective of the level of trade costs. With firm heterogeneity industry-level R\&D spending reaches a minimum strictly between zero and the prohibitive trade cost, as does firm-level R\&D spending in the no-entry case.

The results of our paper are broadly consistent with the recent empirical literature on the effects of trade liberalization on plant productivity, which stresses the importance of firm heterogeneity. The basic complementarity between innovation and exporting captured by our model-namely that firms are more likely to export if they innovate, and are more likely to innovate when they see good export opportunities - is also well documented by these studies (e.g., Lileeva and Trefler (2007), Aw, Roberts and Winston (2007), and Bustos (2007)). There is also empirical evidence that firms try to boost their productivity to increase their market opportunities, which our model predicts to happen in specific cases (see Lopez (2009), Emami-Namini and Lopez (2006), Alvarez and Lopez (2005), and Hallward-Driermeier et al. (2002)). 


\section{Appendix}

\section{A.1 Proof of Lemma 1}

Expected output for the home market is

$$
E[y(c)]=\widehat{y}=g(\widehat{r}) \int_{0}^{\widetilde{c}_{y}} y(c) d F(c)=\frac{g(\widehat{r})}{2} \int_{0}^{\widetilde{c}_{y}}\left[\widetilde{c}_{y}-c\right] d F(c)
$$

and expected exports to the foreign market are

$$
E[x(c)]=\widehat{x}=g(\widehat{r}) \int_{0}^{\widetilde{c}_{x}} x(c) d F(c)=\frac{g(\widehat{r})}{2} \int_{0}^{\widetilde{c}_{x}}\left[\widetilde{c}_{x}-c\right] d F(c) .
$$

Evaluating the integral on the right-hand side of (A.1) by parts, and defining $\phi(c) \equiv\left[\widetilde{c}_{y}-c\right]$, we have

$$
\begin{aligned}
\int_{0}^{\widetilde{c}_{y}}\left[\widetilde{c}_{y}-c\right] d F(c) & =\int_{0}^{\widetilde{c}_{y}} \phi(c) F^{\prime}(c) d c \\
& =\left[\phi\left(\widetilde{c}_{y}\right) F\left(\widetilde{c}_{y}\right)-\phi(0) F(0)\right]-\int_{0}^{\widetilde{c}_{y}} \phi^{\prime}(c) F(c) d c \\
& =\int_{0}^{\widetilde{c}_{y}} F(c) d c,
\end{aligned}
$$

because $\phi\left(\widetilde{c}_{y}\right)=F(0)=0$ and $\phi^{\prime}(c)=-1$. A similar derivation leads to the expected export level.

\section{A.2 Proof of Proposition 1}

This proof has three parts. First, we establish that the second-order conditions of profit maximization are satisfied. Second, we derive the signs of the comparative static effects for the short-run scenario where $N$ is fixed. Third, we sign the comparative static effects for the case of an endogenous market structure.

The Hessian determinant associated with (21), (22) and (23) is equal to

$$
|H|=\left|\begin{array}{ccc}
-2 & 0 & -c^{\prime} \\
0 & -2 & -c^{\prime} \\
-c^{\prime} & -c^{\prime} & \Delta
\end{array}\right|
$$


The first principal minor is -2 , the second principal minor is 4 . The third principal minor, the Hessian itself, is equal to $4\left(\Delta+c^{\prime 2}\right)<0$, since $\Delta+c^{\prime 2}<$ 0 by assumption. This establishes the second-order conditions. For further reference note that $4\left(\Delta+c^{\prime 2}\right)<0$ implies $(2 n+1) \Delta+2 c^{\prime 2}<0$.

In the short run, the equilibrium is determined by (21), (22) and (23). Since $Q=Q^{*}=n(x+y)$ in equilibrium, we can rewrite these conditions as

$$
\begin{aligned}
A-n x-(n+1) y-c & =0, \\
A-n y-(n+1) x-c-t & =0, \\
-c^{\prime}(x+y)-\rho^{\prime} & =0 .
\end{aligned}
$$

Totally differentiating these conditions, we obtain

$$
\left[\begin{array}{ccc}
-(n+1) & -n & -c^{\prime} \\
-n & -(n+1) & -c^{\prime} \\
-c^{\prime} & -c^{\prime} & \Delta
\end{array}\right]\left[\begin{array}{l}
d y \\
d x \\
d r
\end{array}\right]=\left[\begin{array}{l}
0 \\
1 \\
0
\end{array}\right] d t .
$$

The Jacobian determinant $|J|=(2 n+1) \Delta+2 c^{\prime 2}<0$. Using Cramer's Rule the changes with $t$ are thus

$$
\begin{aligned}
\frac{d y}{d t} & =\frac{n \Delta+c^{\prime 2}}{(2 n+1) \Delta+2 c^{\prime 2}}>0, \\
\frac{d x}{d t} & =-\frac{(n+1) \Delta+c^{\prime 2}}{(2 n+1) \Delta+2 c^{\prime 2}}<0, \\
\frac{d r}{d t} & =-\frac{c^{\prime}}{(2 n+1) \Delta+2 c^{\prime 2}}<0 .
\end{aligned}
$$

In the free entry equilibrium, the equilibrium conditions also include the zero-profit condition

$$
(A-n(x+y)-c) y+(A-n(x+y)-c-t) x-\rho-F=0 .
$$

Total differentiation of (A.3) to (A.6) yields

$$
\left[\begin{array}{cccc}
-(n+1) & -n & -c^{\prime} & -(x+y) \\
-n & -(n+1) & -c^{\prime} & -(x+y) \\
-c^{\prime} & -c^{\prime} & \Delta & 0 \\
0 & 0 & 0 & -(x+y)^{2}
\end{array}\right]\left[\begin{array}{l}
d y \\
d x \\
d r \\
d n
\end{array}\right]=\left[\begin{array}{l}
0 \\
1 \\
0 \\
x
\end{array}\right] d t
$$


where the first three zeros in the last row come from the first-order conditions w.r.t. $y, x, r$. The Jacobian determinant is $|J|=-(x+y)^{2}((2 n+1) \Delta+$ $\left.2 c^{\prime 2}\right)>0$. Changes of the endogenous variables with respect to $t$, according to Cramer's Rule, are

$$
\begin{aligned}
\frac{d y}{d t} & =\frac{x \Delta+(x+y)\left(n \Delta+c^{\prime 2}\right)}{(x+y)\left((2 n+1) \Delta+2 c^{\prime 2}\right)}>0 \\
\frac{d x}{d t} & =-\frac{x\left(n \Delta+c^{\prime 2}\right)+y\left((n+1) \Delta+c^{\prime 2}\right)}{(x+y)\left((2 n+1) \Delta+2 c^{\prime 2}\right)}<0 \\
\frac{d r}{d t} & =-\frac{c^{\prime}(y-x)}{(x+y)\left((2 n+1) \Delta+2 c^{\prime 2}\right)}<0 \\
\frac{d n}{d t} & =-\frac{x}{(x+y)^{2}} \leq 0(<0 \text { for } x>0) .
\end{aligned}
$$

\section{A.3 Proof of Proposition 2}

Using (14) and (15) in (16) and (17), and then differentiating (16), (17) and (13) totally, we obtain

$$
\left[\begin{array}{lll}
\alpha_{11} & \alpha_{12} & \alpha_{13} \\
\alpha_{21} & \alpha_{22} & \alpha_{23} \\
\alpha_{31} & \alpha_{32} & \alpha_{33}
\end{array}\right]\left[\begin{array}{l}
d r \\
d \widehat{x} \\
d \widehat{y}
\end{array}\right]=\left[\begin{array}{l}
\beta_{1} \\
\beta_{2} \\
\beta_{3}
\end{array}\right] d t
$$

where

$$
\begin{array}{ccc}
\alpha_{11} \equiv-\frac{2 g^{\prime} \widehat{y}}{g}, & \alpha_{12} \equiv g n F\left(\widetilde{c}_{y}\right), & \alpha_{13} \equiv 2+g(n-1) F\left(\widetilde{c}_{y}\right), \\
\alpha_{21} \equiv-\frac{2 g^{\prime} \widehat{x}}{g}, & \alpha_{22} \equiv 2+g(n-1) F\left(\widetilde{c}_{x}\right), & \alpha_{23} \equiv g n F\left(\widetilde{c}_{x}\right), \\
\alpha_{31} \equiv \widehat{\Pi}_{r r}, & \alpha_{32}=-\frac{4 g^{\prime}}{g}((n-1) \widehat{x}+n \widehat{y}), & \alpha_{33}=-\frac{4 g^{\prime}}{g}((n-1) \widehat{y}+n \widehat{x}), \\
\beta_{1}=0, & \beta_{2}=-g F\left(\widetilde{c}_{x}\right), & \beta_{3}=\frac{4 g^{\prime}}{g} \widehat{x} .
\end{array}
$$

Expanding along the first column yields the determinant

$$
\begin{aligned}
\Phi \equiv & \frac{8 g^{\prime 2}}{g^{2}} \underbrace{\left(\widehat{x}^{2}\left[(2 n-1)\left(1-g F\left(\widetilde{c}_{y}\right)\right)-1\right]+\widehat{y}^{2}\left[(2 n-1)\left(1-g F\left(\widetilde{c}_{x}\right)\right)-1\right]+4 n \widehat{x} \widehat{y}\right)}_{\equiv \Phi_{1}} \\
& +\widehat{\Pi}_{r r} \underbrace{\left(g^{2} n^{2} F\left(\widetilde{c}_{x}\right) F\left(\widetilde{c}_{y}\right)-\left(2+g(n-1) F\left(\widetilde{c}_{y}\right)\right)\left(2+g(n-1) F\left(\widetilde{c}_{x}\right)\right)\right)}_{\equiv \Phi_{2}}
\end{aligned}
$$


We first establish that $\Phi>0$. Since $\operatorname{gnF}\left(\widetilde{c}_{x}\right)<2+g(n-1) F\left(\widetilde{c}_{x}\right)$ and $\operatorname{gnF}\left(\widetilde{c}_{y}\right)<2+g(n-1) F\left(\widetilde{c}_{y}\right), \Phi_{2}<0$ and hence $\widehat{\Pi}_{r r} \Phi_{2}>0$. Thus, $\Phi>0$ will hold true if we can show that $\Phi_{1}>0$. We will show that $\Phi_{1}>0$ by contradiction. We observe first that $\Phi_{1}>0$ if $(2 n-1)\left(1-g F\left(\widetilde{c}_{y}\right)\right)-1 \geq 0$ and $(2 n-1)\left(1-g F\left(\widetilde{c}_{x}\right)\right)-1 \geq 0$. Thus, $\Phi_{1}<0$ requires that $(2 n-1)(1-$ $\left.g F\left(\widetilde{c}_{y}\right)\right)-1<0$ and/or $(2 n-1)\left(1-g F\left(\widetilde{c}_{x}\right)\right)-1<0$. Since $g F\left(\widetilde{c}_{y}\right) \geq g F\left(\widetilde{c}_{x}\right)$, $(2 n-1)\left(1-g F\left(\widetilde{c}_{x}\right)\right)-1 \geq(2 n-1)\left(1-g F\left(\widetilde{c}_{y}\right)\right)-1$, and we have to consider two possible cases:

Case 1: $(2 n-1)\left(1-g F\left(\widetilde{c}_{x}\right)\right)-1>0,(2 n-1)\left(1-g F\left(\widetilde{c}_{y}\right)\right)-1<0$

In this case,

$\Phi_{1}>\widehat{x}^{2}\left[(2 n-1)\left(1-g F\left(\widetilde{c}_{y}\right)\right)-1\right]+4 n \widehat{x} \widehat{y}=\widehat{x}\left(\widehat{x}\left[(2 n-1)\left(1-g F\left(\widetilde{c}_{y}\right)\right)-1\right]+4 n \widehat{y}\right)>0$ because $\widehat{y}>\widehat{x}$ and $4 n>-(2 n-1)\left(1-g F\left(\widetilde{c}_{y}\right)\right)+1$.

Case 2: $(2 n-1)\left(1-g F\left(\widetilde{c}_{x}\right)\right)-1<0,(2 n-1)\left(1-g F\left(\widetilde{c}_{y}\right)\right)-1<0$

First observe that for zero trade costs, $\widehat{x}=\widehat{y}, F\left(\widetilde{c}_{x}\right)=F\left(\widetilde{c}_{y}\right)$ and

$$
\Phi_{1}=2 \widehat{y}^{2}(2 n-1)\left(2-g F\left(\widetilde{c}_{y}\right)\right)>0
$$

Hence, $\Phi_{1}<0$ warrants the existence of a critical $\bar{x}<\widehat{y}$ such that

$$
\bar{x}^{2}\left[(2 n-1)\left(1-g F\left(\widetilde{c}_{y}\right)\right)-1\right]+\widehat{y}^{2}\left[(2 n-1)\left(1-g F\left(\widetilde{c}_{x}\right)\right)-1\right]+4 n \bar{x} \widehat{y}=0 .
$$

Solving for quadratic equation yields the two solutions

$$
\bar{x}_{1,2}=\frac{-4 n \widehat{y} \pm \sqrt{8 n^{2} \widehat{y}^{2}-4\left[(2 n-1)\left(1-g F\left(\widetilde{c}_{y}\right)\right)-1\right]\left[(2 n-1)\left(1-g F\left(\widetilde{c}_{x}\right)\right)-1\right] \widehat{y}^{2}}}{(2 n-1)\left(1-g F\left(\widetilde{c}_{y}\right)\right)-1}
$$

Note carefully that $(2 n-1)\left(1-g F\left(\widetilde{c}_{y}\right)\right)-1 \in[-1,0]$ so that $\bar{x}$ is larger than the numerator in absolute terms. The negative solution is irrelevant as it implied $\bar{x}>4 n \widehat{y}$ which violates $\bar{x}<\widehat{y}$. The positive solution fulfills $\bar{x}<\widehat{y}$ only if

$$
\begin{aligned}
& \sqrt{8 n^{2} \widehat{y}^{2}-4\left[(2 n-1)\left(1-g F\left(\widetilde{c}_{y}\right)\right)-1\right]\left[(2 n-1)\left(1-g F\left(\widetilde{c}_{x}\right)\right)-1\right] \widehat{y}^{2}} \\
> & (4 n-1) \widehat{y} .
\end{aligned}
$$


However,

$$
\begin{aligned}
& \sqrt{8 n^{2} \widehat{y}^{2}-4\left[(2 n-1)\left(1-g F\left(\widetilde{c}_{y}\right)\right)-1\right]\left[(2 n-1)\left(1-g F\left(\widetilde{c}_{x}\right)\right)-1\right] \widehat{y}^{2}} \\
< & \sqrt{8 n^{2} \widehat{y}^{2}}=2 \sqrt{2} n \widehat{y}<(4 n-1) \widehat{y}
\end{aligned}
$$

so that no solution exists in the relevant range and $\Phi_{1}>0$ holds also for that case. This proves that $\Phi>0$.

We can now derive the comparative-static effects:

$$
\begin{gathered}
\frac{d \widehat{r}}{d t}=\frac{8 g^{\prime}}{g \Phi}\left(g n\left(\widehat{y} F\left(\widetilde{c}_{x}\right)-\widehat{x} F\left(\widetilde{c}_{y}\right)\right)-\widehat{x}\left(2-g F\left(\widetilde{c}_{y}\right)\right)\right), \\
\frac{d \widehat{x}}{d t}=-\frac{8 g^{\prime 2}}{g^{2} \Phi}\left(2 \widehat{x}^{2}+g(n-1)\left[\widehat{y}^{2} F\left(\widetilde{c}_{x}\right)+\widehat{x}^{2} F\left(\widetilde{c}_{y}\right)\right]\right) \\
+\frac{\widehat{\Pi}_{r r}}{\Phi} g F\left(\widetilde{c}_{x}\right)\left(2+g(n-1) F\left(\widetilde{c}_{y}\right)\right) \leq 0(<0 \text { for } x>0) . \\
\frac{d \widehat{y}}{d t}=\frac{8 g^{\prime 2}}{g^{2} \Phi}\left(g n\left[\widehat{y}^{2} F\left(\widetilde{c}_{x}\right)+\widehat{x}^{2} F\left(\widetilde{c}_{y}\right)\right]-2 \widehat{x} \widehat{y}\right)-\frac{\widehat{\Pi}_{r r}}{\Phi} g^{2} n F\left(\widetilde{c}_{x}\right) F\left(\widetilde{c}_{y}\right) .
\end{gathered}
$$

For the critical values of marginal costs we obtain

$$
\begin{aligned}
\frac{d \widetilde{c}_{y}}{d t} & =-(n-1) \frac{d \widehat{q}}{d t}-\frac{d \widehat{x}}{d t} \\
& =-2 n \frac{\widehat{\Pi}_{r r}}{\Phi} g F\left(\widetilde{c}_{x}\right)+\frac{16 g^{\prime 2}}{g^{2} \Phi}\left(n \widehat{x}^{2}+(n-1) \widehat{x} \widehat{y}\right) \geq 0(>0 \text { for } \widehat{x}>0),
\end{aligned}
$$

and

$$
\begin{aligned}
\frac{d \widetilde{c}_{x}}{d t} & =-(n-1) \frac{d \widehat{x}}{d t}-n \frac{d \widehat{y}}{d t}-1 \\
& =\frac{2}{g^{2} \Phi}\left(2 g^{2} \widehat{\Pi}_{r r}+g^{3}(n-1) F\left(\widetilde{c}_{y}\right) \widehat{\Pi}_{r r}-8 g^{2} \widehat{y}(n(\widehat{x}+\widehat{y})-\widehat{y})\right)<0
\end{aligned}
$$

where

$$
\left.\frac{d \widetilde{c}_{y}}{d t}\right|_{\widehat{x}=0}=0,\left.\frac{d \widetilde{c}_{x}}{d t}\right|_{\widehat{x}=0}=-1 .
$$

Evaluating the derivatives of $\widehat{r}$ and $\widehat{y}$ at $t=0$ (where $\widehat{x}=\widehat{y}$ and thus $\left.F\left(\widetilde{c}_{x}\right)=F\left(\widetilde{c}_{y}\right)\right)$ and for prohibitive trade costs $\left(x=0\right.$ and thus $\left.F\left(\widetilde{c}_{x}\right)=0\right)$, we get

$$
\left.\frac{d \widehat{r}}{d t}\right|_{\widehat{x}=\widehat{y}}<0,\left.\frac{d r}{d t}\right|_{x=0}=0,\left.\frac{d \widehat{x}}{d t}\right|_{\widehat{x}=0}=0,\left.\frac{d \widehat{y}}{d t}\right|_{\widehat{x}=0}=0
$$




$$
\left.\frac{d \widehat{y}}{d t}\right|_{\widehat{x}=\widehat{y}}=-\frac{16 g^{\prime 2} \widehat{y}^{2}}{g^{2} \Phi}\left(1-n g F\left(\widetilde{c}_{y}\right)\right)-\frac{\widehat{\Pi}_{r r}}{\Phi} g^{2} n F\left(\widetilde{c}_{x}\right) F\left(\widetilde{c}_{y}\right) \text { is ambiguous. }
$$

Hence, $\widehat{r}, \widehat{x}$ and $\widehat{y}$ have an extremum or a saddle point at $\widehat{x}=0$. Further differentiation yields

$$
\begin{gathered}
\left.\frac{d^{2} \widehat{r}}{d t^{2}}\right|_{\widehat{x}=0}=-\frac{8 g^{\prime} \widehat{y} f\left(\widetilde{c}_{x}\right)}{\Phi}<0, \\
\left.\frac{d^{2} \widehat{x}}{d t^{2}}\right|_{\widehat{x}=0}=\frac{8 g^{\prime 2}}{g^{2} \Phi} g(n-1) \widehat{y}^{2} f\left(\widetilde{c}_{x}\right)-\frac{\widehat{\Pi}_{r r}}{\Phi} g f\left(\widetilde{c}_{x}\right)\left(2+g(n-1) F\left(\widetilde{c}_{y}\right)\right)>0, \\
\left.\left.\frac{d^{2} \widehat{y}}{d t^{2}}\right|_{\widehat{x}=0}=-\frac{8 g^{\prime 2}}{g \Phi}(n-1) \widehat{y}^{2} f\left(\widetilde{c}_{x}\right)+\frac{\widehat{\Pi}_{r r}}{\Phi} n g^{2} f\left(\widetilde{c}_{x}\right) F\left(\widetilde{c}_{y}\right)\right)<0,
\end{gathered}
$$

where $f\left(\widetilde{c}_{x}\right)=F^{\prime}\left(\widetilde{c}_{x}\right)>0$ is the density at the critical cost level of exports. Consequently, both $\widehat{r}$ and $\widehat{y}$ have a local maximum at $\widehat{x}=0$, while $\widehat{x}$ has a local minimum. Since $\widehat{r}$ declines with $t$ at $t=0$, there must exist a global minimum strictly between free trade and the prohibitive trade cost level.

The change in total expected output per firm, $\widehat{q} \equiv \widehat{y}+\widehat{x}$, given by $\frac{d \widehat{q}}{d t}=-\frac{8 g^{\prime 2}}{g^{2} \Phi}\left(\widehat{x}^{2}\left[2-g F\left(\widetilde{c}_{y}\right)\right]+\widehat{y}\left[2 \widehat{x}-\widehat{y} g F\left(\widetilde{c}_{x}\right]\right)+\frac{\widehat{\Pi}_{r r}}{\Phi} F\left(\widetilde{c}_{x}\right)\left(g\left(2-g F\left(\widetilde{c}_{y}\right)\right)\right)\right.$ is ambiguous. In particular,

$$
\begin{gathered}
\left.\frac{d \widehat{q}}{d t}\right|_{\widehat{x}=0}=0, \\
\left.\frac{d \widehat{q}}{d t}\right|_{\widehat{x}=\widehat{y}}=-\frac{16 g^{\prime 2}}{g^{2} \Phi} \widehat{y}^{2}\left[2-g F\left(\widetilde{c}_{y}\right)\right]+\frac{\widehat{\Pi}_{r r}}{\Phi} F\left(\widetilde{c}_{x}\right)\left(g\left(2-g F\left(\widetilde{c}_{y}\right)\right)\right)<0 .
\end{gathered}
$$

Since

$$
\left.\frac{d^{2} \widehat{q}}{d t^{2}}\right|_{\widehat{x}=0}=-\frac{8 g^{\prime 2}}{g^{2} \Phi} \widehat{y}^{2} f\left(\widetilde{c}_{x}\right)-\frac{\widehat{\Pi}_{r r}}{\Phi} f\left(\widetilde{c}_{x}\right)\left(g\left(2-g F\left(\widetilde{c}_{y}\right)\right)\right) \text { is ambiguous, }
$$

it is not clear whether output per firm has a local minimum or a local maximum at $\widehat{x}=0$. 
Using $d G(c)=g(\widehat{r}) d F(c) \equiv g(\widehat{r}) f(c) d c$, the effect of trade liberalization on industry productivity is calculated as follows:

$$
\begin{aligned}
\frac{d}{d t} E\left(c \mid \leq \widetilde{c}_{y}\right) & =\frac{d}{d t} \frac{1}{G\left(\widetilde{c}_{y}\right)} \int_{0}^{\widetilde{c}_{y}} c d G(c) \\
& =\frac{1}{G\left(\widetilde{c}_{y}\right)} \widetilde{c}_{y} g(\widehat{r}) f\left(\widetilde{c}_{y}\right) \frac{d \widetilde{c}_{y}}{d t}-\left[\int_{0}^{\widetilde{c}_{y}} c d G\right] \frac{g(\widehat{r}) f\left(\widetilde{c}_{y}\right)}{G\left(\widetilde{c}_{y}\right)^{2}} \frac{d \widetilde{c}_{y}}{d t} \\
& =\frac{1}{G\left(\widetilde{c}_{y}\right)} g(\widehat{r}) f\left(\widetilde{c}_{y}\right)\left[\widetilde{c}_{y}-E\left(c \mid c \leq \widetilde{c}_{y}\right)\right] \frac{d \widetilde{c}_{y}}{d t}>0,
\end{aligned}
$$

because $d \widetilde{c}_{y} / d t>0$.

\section{A.4 Proof of Proposition 3}

Differentiating (27), (28) and (29) totally, we get

$$
\left[\begin{array}{lll}
a_{11} & a_{12} & a_{13} \\
a_{21} & a_{22} & a_{23} \\
a_{31} & a_{32} & a_{33}
\end{array}\right]\left[\begin{array}{l}
d n \\
d \widehat{x} \\
d \widehat{y}
\end{array}\right]=\left[\begin{array}{l}
b_{1} \\
b_{2} \\
b_{3}
\end{array}\right] d t
$$

where

$$
\begin{aligned}
a_{11} \equiv(\widehat{x}+\widehat{y}) G\left(\widetilde{c}_{y}\right), & a_{12} \equiv n G\left(\widetilde{c}_{y}\right), & a_{13} \equiv 2+(n-1) G\left(\widetilde{c}_{y}\right), \\
a_{21} \equiv(\widehat{x}+\widehat{y}) G\left(\widetilde{c}_{x}\right), & a_{22} \equiv 2+(n-1) G\left(\widetilde{c}_{x}\right), & a_{23} \equiv n G\left(\widetilde{c}_{x}\right), \\
a_{31} \equiv-4(\widehat{x}+\widehat{y})^{2}, & a_{32}=-4((n-1) \widehat{x}+n \widehat{y}), & a_{33}=-4((n-1) \widehat{y}+n \widehat{x}), \\
b_{1}=0, & b_{2}=-G\left(\widetilde{c}_{x}\right), & b_{3}=4 \widehat{x} .
\end{aligned}
$$

The determinant is

$$
\Gamma \equiv 8(\widehat{x}+\widehat{y})\left[\widehat{x}\left(2-G\left(\widetilde{c}_{y}\right)\right)+\widehat{y}\left(2-G\left(\widetilde{c}_{x}\right)\right)\right]>0 .
$$

The comparative-static effects are given by

$$
\begin{aligned}
& \frac{d n}{d t}=\frac{8 n\left(\widehat{y} G\left(\widetilde{c}_{x}\right)-\widehat{x} G\left(\widetilde{c}_{y}\right)\right)-\left(2-G\left(\widetilde{c}_{y}\right)\right) \widehat{x}}{\Gamma}, \\
& \frac{d \widehat{x}}{d t}=-\frac{8 \widehat{y}(\widehat{x}+\widehat{y}) G\left(\widetilde{c}_{x}\right)}{\Gamma} \leq 0(<0 \text { for } \widehat{x}>0), \\
& \frac{d \widehat{y}}{d t}=\frac{8 \widehat{x}(\widehat{x}+\widehat{y}) G\left(\widetilde{c}_{y}\right)}{\Gamma} \geq 0(>0 \text { for } \widehat{x}>0),
\end{aligned}
$$




$$
\frac{d \widehat{q}}{d t}=\frac{8(\widehat{x}+\widehat{y})\left(\widehat{x} G\left(\widetilde{c}_{y}\right)-\widehat{y} G\left(\widetilde{c}_{x}\right)\right)}{\Gamma} .
$$

Furthermore, as $\left.G\left(\widetilde{c}_{y}\right)\right|_{\widehat{x}=\widehat{y}}=\left.G\left(\widetilde{c}_{x}\right)\right|_{\widehat{x}=\widehat{y}}$, we have

$$
\left.\frac{d \widehat{y}}{d t}\right|_{\widehat{x}=\widehat{y}}=-\left.\frac{d \widehat{x}}{d t}\right|_{\widehat{x}=\widehat{y}}<0 .
$$

Noting that

$$
\begin{aligned}
\frac{d \widetilde{c}_{y}}{d t} & =-(n-1) \frac{d \widehat{y}}{d t}-n \frac{d \widehat{x}}{d t}-(\widehat{y}+\widehat{x}) \frac{d n}{d t} \\
\frac{d \widetilde{c}_{x}}{d t} & =-(n-1) \frac{d \widehat{x}}{d t}-n \frac{d \widehat{y}}{d t}-(\widehat{y}+\widehat{x}) \frac{d n}{d t}-1
\end{aligned}
$$

we obtain

$$
\begin{aligned}
\frac{d \widetilde{c}_{y}}{d t} & =\frac{\widehat{x}\left(2+7 G\left(\widetilde{c}_{y}\right)\right)}{8\left(\left(2-G\left(\widetilde{c}_{y}\right)\right) \widehat{x}+\left(2-G\left(\widetilde{c}_{x}\right)\right) \widehat{y}\right)} \geq 0(>0 \text { for } \widehat{x}>0), \\
\frac{d \widetilde{c}_{x}}{d t} & =-\frac{7 \widehat{x}\left(2-G\left(\widetilde{c}_{y}\right)\right)+16 \widehat{y}}{8\left(\left(2-G\left(\widetilde{c}_{y}\right)\right) \widehat{x}+\left(2-G\left(\widetilde{c}_{x}\right)\right) \widehat{y}\right)}<0,
\end{aligned}
$$

where

$$
\left.\frac{d \widetilde{c}_{y}}{d t}\right|_{\widehat{x}=0}=0,\left.\frac{d \widetilde{c}_{x}}{d t}\right|_{\widehat{x}=0}=-1 .
$$

The effects of trade liberalization on $n$ and $\hat{q}$ are generally ambiguous, but can be evaluated at free trade and at the prohibitive level of trade costs. Using $g(\cdot)=G^{\prime}(\cdot)$, the marginal effect on $n$ is:

$$
\left.\frac{d n}{d t}\right|_{\widehat{x}=\widehat{y}}<0,\left.\frac{d n}{d t}\right|_{\widehat{x}=0}=0,\left.\frac{d^{2} n}{d t^{2}}\right|_{\widehat{x}=0}=-\frac{8 n \widehat{y}^{2} g\left(\widetilde{c}_{x}\right)}{\Gamma}<0 .
$$

Hence, $n$ has a local maximum at $\widehat{x}=0$. Since $n$ decreases with $t$ close to $t=0$, it follows that $n$ must have an interior minimum between $t=0$ and the prohibitive trade cost level. As per-firm R\&D is constant, this implies that aggregate $R \& D$, too, must have an interior minimum.

With respect to total expected firm output we find

$$
\begin{gathered}
\left.\frac{d \widehat{q}}{d t}\right|_{\widehat{x}=\widehat{y}}=0 \\
\left.\frac{d^{2} \widehat{q}}{d t^{2}}\right|_{\widehat{x}=\widehat{y}}=\frac{16 \widehat{y}}{\Gamma}\left(2 \frac{d \widehat{x}}{d t} G\left(\widetilde{c}_{x}\right)+\widehat{x} g\left(\widetilde{c}_{x}\right)\left(\frac{d \widetilde{c}_{y}}{d t}-\frac{d \widetilde{c}_{x}}{d t}\right)\right) \text { is ambiguous, }
\end{gathered}
$$




$$
\left.\frac{d \widehat{q}}{d t}\right|_{\widehat{x}=0}=0,\left.\frac{d^{2} \widehat{q}}{d t^{2}}\right|_{\widehat{x}=0}=\frac{8 \widehat{y}^{2} g\left(\widetilde{c}_{x}\right)}{\Gamma}>0 .
$$

This implies that $\widehat{q}$ has a local minimum at $\widehat{x}=0$. We cannot determine without further assumptions whether $\widehat{q}$ has a local minimum or a local maximum at $t=0$.

Note from (A.11) that the effect of trade liberalization on industry productivity is positive since $d \widetilde{c}_{y} / d t \geq 0(>0$ for $\widehat{x}>0)$.

\section{A.5 Welfare Effects with Homogeneous Firms}

When the number of firms is fixed, welfare in each country is equal to $W=$ $A Q-Q^{2} / 2-c Q-\operatorname{tn} x-n \rho$ with $Q=n(x+y)$. Differentiation yields

$$
\begin{aligned}
\frac{\partial W}{\partial x} & =n(A-n(x+y)-c-t), \\
\frac{\partial W}{\partial y} & =n(A-n(x+y)-c), \\
\frac{\partial W}{\partial t} & =-n x, \\
\frac{\partial W}{\partial r} & =n\left(-c^{\prime}(x+y)-\rho^{\prime}\right)=0 .
\end{aligned}
$$

A marginal change in $t$ affects welfare as follows:

$$
\begin{aligned}
\frac{d W}{d t} & =n\left(\frac{\partial W}{\partial x} \frac{d x}{d t}+\frac{\partial W}{\partial y} \frac{d y}{d t}\right)+\frac{\partial W}{\partial t} \\
& =\frac{n((n y-(3 n+2) x) \Delta)+(y-3 x) c^{\prime 2}}{(2 n+1) \Delta+2 c^{\prime 2}} .
\end{aligned}
$$

Evaluating the derivative at zero trade $\operatorname{costs}(t=0$ and hence $x=y)$ and for prohibitive trade costs $(x=0)$, we obtain

$$
\begin{aligned}
\left.\frac{d W}{d t}\right|_{x=y} & =-n y\left(1+\frac{\Delta}{(2 n+1) \Delta+2 c^{\prime 2}}\right)<0, \\
\left.\frac{d W}{d t}\right|_{x=0} & =\frac{n y\left(n \Delta+c^{\prime 2}\right)}{(2 n+1) \Delta+2 c^{\prime 2}}>0
\end{aligned}
$$


respectively.

When the market structure is endogenous, social welfare is equal to consumer surplus, i.e., $W=Q^{2} / 2$. Using (A.7), (A.8) and (A.10), we have:

$\frac{d Q}{d t}=n\left(\frac{d y}{d t}+\frac{d x}{d t}\right)+\frac{d n}{d t}(x+y)=-\frac{x\left((n+1+n y / x) \Delta+2 c^{\prime 2}\right)}{(x+y)\left((2 n+1) \Delta+2 c^{\prime 2}\right)} \leq 0(<0$ for $x>0)$.

\section{A.6 Welfare Effects with Heterogeneous Firms}

In the case of a fixed number of entrants, the welfare effect of integration consists of the effect on aggregate expected profits and consumer surplus. The change in expected profit (18) is

$$
\begin{aligned}
\frac{d \widehat{\Pi}}{d t} & =\frac{g(\widehat{r})}{4}\left(\frac{\partial \Omega}{\partial \widehat{y}} \frac{d \widehat{y}}{d t}+\frac{\partial \Omega}{\partial \widehat{x}} \frac{d \widehat{x}}{d t}\right) \\
& =-(n-1) \frac{d \widehat{q}}{d t} \widehat{q}+\frac{d \widehat{y}}{d t} \widehat{x}-\frac{d \widehat{x}}{d t} \widehat{y}-\widehat{x},
\end{aligned}
$$

taking into account that $\partial \widehat{\Pi} / \partial r=0$. Let $\widehat{C S} \equiv(n \widehat{q})^{2} / 2$ denote expected consumer surplus. Its change with $t$ is

$$
\frac{d \widehat{C S}}{d t}=n^{2} \widehat{q} \frac{d \widehat{q}}{d t}<0
$$

since $d \widehat{q} / d t<0$. The total expected welfare change is determined as

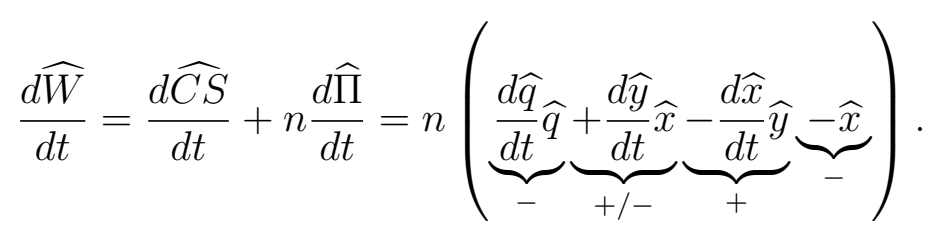

For $t=0$ (where $\widehat{x}=\widehat{y}$ and thus $\left.F\left(\widetilde{c}_{x}\right)=F\left(\widetilde{c}_{y}\right)\right)$, we obtain

$$
\begin{gathered}
\left.\frac{d \widehat{W}}{d t}\right|_{t=0}=\frac{n \widehat{y}}{\Phi} \times \\
\left(2 \widehat{\Pi}_{r r}\left(2-g F\left(\widetilde{c}_{y}\right)+2 g n F\left(\widetilde{c}_{y}\right)\left(1-g F\left(\widetilde{c}_{y}\right)\right)\right)-\frac{32 g^{\prime 2} \widehat{y}^{2}}{g^{2}}\left(1+2 n\left(1-g F\left(\widetilde{c}_{y}\right)\right)\right)\right)<0 .
\end{gathered}
$$


At the prohibitive trade cost level, i.e., for $\widehat{x}=0, F\left(\widetilde{c}_{x}\right)=0, \widehat{q}=\widehat{y}$, we find that

$$
\begin{aligned}
\left.\frac{d \widehat{W}}{d t}\right|_{\widehat{x}=0} & =0 \\
\left.\frac{d^{2} \widehat{W}}{d t^{2}}\right|_{\widehat{x}=0} & =n \widehat{q}\left(\frac{d^{2} \widehat{q}}{d t^{2}}-\frac{d^{2} \widehat{x}}{d t^{2}}\right)<0
\end{aligned}
$$

because

$$
\frac{d^{2} \widehat{q}}{d t^{2}}-\frac{d^{2} \widehat{x}}{d t^{2}}=-\frac{8 g^{\prime 2}}{g} n \widehat{y}^{2} f\left(\widetilde{c}_{x}\right)+\frac{g^{2}}{\Phi} \widehat{\Pi}_{r r} F\left(\widetilde{c}_{y}\right) f\left(\widetilde{c}_{x}\right)<0 .
$$

Hence welfare has a local maximum at $\widehat{x}=0$. This, together with the fact that welfare decreases with $t$ when $t$ is near zero, implies that social welfare has an interior minimum.

In the case of an endogenous market structure, as profits are zero due to free entry, the welfare effect of trade liberalization is identical in sign to the effect on total industry output:

$$
\begin{aligned}
\frac{d Q}{d t} & =\widehat{q} \frac{d n}{d t}+n \frac{d \widehat{q}}{d t} \\
& =-\frac{\widehat{x}(\widehat{x}+\widehat{y})\left(2-G\left(\widetilde{c}_{y}\right)\right)}{\Gamma} \leq 0(<0 \text { for } \widehat{x}>0)
\end{aligned}
$$

\section{References}

[1] Aghion, P., Griffith, R., 2005. Competition and Growth. MIT Press, Cambridge, MA.

[2] Aghion, P., Bloom, N., Blundell, R., Griffith, R., Howitt, P., 2005. Competition and innovation: an inverted-U relationship. Quarterly Journal of Economics 120, 701-28.

[3] Aghion, P., Blundell, R., R. Griffith, Howitt, P., Prantl, S., 2004. Entry and productivity growth: evidence from microlevel panel data. Journal of the European Economic Association 2, 265-276. 
[4] Alvarez, R., Lopez, R.A., 2005. Exporting and performance: evidence from Chilean plants. Canadian Journal of Economics 38, 1384-1400.

[5] Atkeson, A., Burstein, A., 2006. Innovation, firm dynamics, and international trade. UCLA, mimeo.

[6] Aw, B.Y., Roberts, M. J., Winston, T., 2007. Export market participation, investments in R\&D and worker training, and the evolution of firm productivity. The World Economy 30, 83-104.

[7] Baldwin, R.E., Robert-Nicoud, F., 2008. Trade and growth with heterogeneous firms. Journal of International Economics 74, 21-34.

[8] Brander, J.A., 1981. Intra-industry trade in identical commodities. Journal of International Economics 11, 1-14.

[9] Brander, J.A., Krugman, P.R., 1983. A reciprocal dumping model of international trade. Journal of International Economics 15, 313-323.

[10] Bustos, P., 2007. Multilateral trade liberalization, exports and technology upgrading: Evidence on the impact of MERCOSUR on Argentinean firms. Universitat Pompeu Fabra, mimeo.

[11] Costantini, J.A., Melitz, M.J., 2008. The dynamics of firm-level adjustment to trade liberalization, in: Helpman, E., Marin, D., Verdier, T. (Eds.), The Organization of Firms in a Global Economy, Harvard University Press, Cambridge, MA, pp. 107-141.

[12] Cramton, P.C., Palfrey, T.R., 1990. Cartel enforcement with uncertainty about cost. International Economic Review 31, 17-47.

[13] Dasgupta, P., Stiglitz, J., 1980. Industrial structure and the nature of innovative activity. Economic Journal 90, 266-293.

[14] Eaton, J., Kortum, S. 2001. Technology, trade, and growth: A unified framework. European Economic Review 45, 742-755. 
[15] Ederington, J., McCalman, P., 2008. Endogenous firm heterogeneity and the dynamics of trade liberalization. Journal of International Economics $74,422-440$.

[16] Emami Namini, J., Lopez, R.A., 2006. Random versus conscious selection into export markets: theory and empirical evidence. Indiana University, mimeo.

[17] Fernandes, A., 2007. Trade policy, trade volumes and plant-level productivity in Colombian manufacturing industries. Journal of International Economics 71, 52-71.

[18] Greenaway, D., Kneller, R., 2007. Firm heterogeneity, exporting and foreign direct investment. Economic Journal 117, F134-161.

[19] Gustafsson, P., Segerstrom, P., 2006. Trade liberalization and productivity growth. Stockholm School of Economics, mimeo.

[20] Haaland, J., Kind, H. 2008. R\&D policies, trade and process innovation. Journal of International Economics 74, 170-187.

[21] Hallward-Driermeier, M., Iarossi, G., Sokoloff, K.L., 2002. Exports and manufacturing productivity in East Asia: A comparative analysis with firm-level data. NBER Working Paper 8894.

[22] Licandro, O., Navas-Ruiz, A. 2008. Trade liberalization, competition and growth. European University Institute, mimeo.

[23] Lileeva, A., Trefler, D., 2007. Improved access to foreign markets raises plant-level productivity. . . for some plants. York University and University of Toronto, mimeo.

[24] Lopez, R.A., 2009. Do firms increase productivity in order to become exporters? Oxford Bulletin of Economics and Statistics 71, 621-642.

[25] Melitz, M.J., 2003. The impact of trade on intra-industry reallocations and aggregate industry productivity. Econometrica 71, 1695-1725. 
[26] Melitz, M.J., Ottaviano, G.I.P., 2008. Market size, trade, and productivity. Review of Economic Studies 75, 295-316..

[27] Navas, A., Sala, D., 2007. Technology adoption and the selection effect of trade, EUI ECO Working Paper 2007/58.

[28] Tybout, J., 2003. Plant- and firm-level evidence on "new" trade theories, in: Choi, E.K., Harrigan, J. (Eds.): Handbook of International Trade. Blackwell, Oxford.

[29] Vannoorenberghe, G., 2008. Globalisation, heterogeneous firms and endogenous investment. University of Mannheim, mimeo.

[30] Wagner, J., 2007. Exports and productivity: A survey of the evidence from firm-level data. The World Economy 30, 60-82.

[31] Yeaple, S., 2005. A simple model of firm heterogeneity, international trade and wages. Journal of International Economics 65, 1-20. 


\section{CESifo Working Paper Series}

for full list see www.cesifo-group.org/wp

(address: Poschingerstr. 5, 81679 Munich, Germany, office@cesifo.de)

2733 Francesco Cinnirella and Joachim Winter, Size Matters! Body Height and Labor Market Discrimination: A Cross-European Analysis, July 2009

2734 Samuel Bowles and Sandra Polanía Reyes, Economic Incentives and Social Preferences: A Preference-based Lucas Critique of Public Policy, July 2009

2735 Gary Burtless, Lessons of the Financial Crisis for the Design of National Pension Systems, July 2009

2736 Helmuth Cremer, Firouz Gahvari and Pierre Pestieau, Fertility, Human Capital Accumulation, and the Pension System, July 2009

2737 Hans Jarle Kind and Frank Stähler, Market Shares in Two-Sided Media Industries, July 2009

2738 Pamela Campa, Alessandra Casarico and Paola Profeta, Gender Culture and Gender Gap in Employment, August 2009

2739 Sebastian Gechert, Supplementary Private Health Insurance in Selected Countries: Lessons for EU Governments?, August 2009

2740 Leif Danziger, Endogenous Monopsony and the Perverse Effect of the Minimum Wage in Small Firms, August 2009

2741 Yan Dong and John Whalley, A Third Benefit of Joint Non-OPEC Carbon Taxes: Transferring OPEC Monopoly Rent, August 2009

2742 Valentina Bosetti, Carlo Carraro and Massimo Tavoni, Climate Change Mitigation Strategies in Fast-Growing Countries: The Benefits of Early Action, August 2009

2743 Christina Felfe, The Willingness to Pay for Job Amenities: Evidence from Mothers' Return to Work, August 2009

2744 Jörg Franke, Christian Kanzow, Wolfgang Leininger and Alexandra Väth, Effort Maximization in Asymmetric N-Person Contest Games, August 2009

2745 Bruno S. Frey and Paolo Pamini, Making World Heritage Truly Global: The Culture Certificate Scheme, August 2009

2746 Frank N. Caliendo, Is Social Security behind the Collapse of Personal Saving?, August 2009

2747 Caterina Liesegang and Marco Runkel, Corporate Income Taxation of Multinationals and Fiscal Equalization, August 2009 
2748 Chrysovalantou Milliou and Apostolis Pavlou, Upstream Horizontal Mergers and Efficiency Gains, August 2009

2749 Rüdiger Pethig and Christian Wittlich, Interaction of Carbon Reduction and Green Energy Promotion in a Small Fossil-Fuel Importing Economy, August 2009

2750 Kai Carstensen, Oliver Hülsewig and Timo Wollmershäuser, Monetary Policy Transmission and House Prices: European Cross-country Evidence, August 2009

2751 Olaf Posch, Explaining Output Volatility: The Case of Taxation, August 2009

2752 Beatrice Scheubel, Daniel Schunk and Joachim Winter, Don't Raise the Retirement Age! An Experiment on Opposition to Pension Reforms and East-West Differences in Germany, August 2009

2753 Daniel G. Arce, Dan Kovenock and Brian Roberson, Suicide Terrorism and the Weakest Link, August 2009

2754 Mario Larch and Wolfgang Lechthaler, Comparative Advantage and Skill-Specific Unemployment, August 2009

2755 Horst Raff and Nicolas Schmitt, Buyer Power in International Markets, August 2009

2756 Seppo Kari, Hanna Karikallio and Jukka Pirttilä, The Impact of Dividend Taxation on Dividends and Investment: New Evidence Based on a Natural Experiment, August 2009

2757 Mirco Tonin and Michael Vlassopoulos, Disentangling the Sources of Pro-social Behavior in the Workplace: A Field Experiment, August 2009

2758 Nicole Grunewald and Inmaculada Martínez-Zarzoso, Driving Factors of Carbon Dioxide Emissions and the Impact from Kyoto Protocol, August 2009

2759 Yu-Fu Chen and Michael Funke, Booms, Recessions and Financial Turmoil: A Fresh Look at Investment Decisions under Cyclical Uncertainty, August 2009

2760 Jan-Egbert Sturm and Jakob de Haan, Does Central Bank Communication really Lead to better Forecasts of Policy Decisions? New Evidence Based on a Taylor Rule Model for the ECB, August 2009

2761 Larry Karp, Sacrifice, Discounting and Climate Policy: Five Questions, August 2009

2762 Marianna Belloc and Samuel Bowles, International Trade, Factor Mobility and the Persistence of Cultural-Institutional Diversity, August 2009

2763 Charles Noussair and Fangfang Tan, Voting on Punishment Systems within a Heterogeneous Group, August 2009

2764 Birgit Bednar-Friedl and Karl Farmer, Internationally Coordinated Emission Permit Policies: An Option for Withdrawers from the Kyoto Protocol?, August 2009 
2765 Pierre M. Picard and David E. Wildasin, Labor Market Pooling, Outsourcing and Labor Contracts, August 2009

2766 Stefan Voigt and Lorenz Blume, The Economic Effects of Federalism and Decentralization - A Cross-Country Assessment, August 2009

2767 David S. Jacks, Christopher M. Meissner and Dennis Novy, Trade Booms, Trade Busts, and Trade Costs, August 2009

2768 Mario Jametti and Thomas von Ungern-Sternberg, Hurricane Insurance in Florida, August 2009

2769 Alessandro Balestrino, Kind of Black: The Musicians’ Labour Market in Italy, August 2009

2770 Yosr Abid Fourati and Cathal O’Donoghue, Eliciting Individual Preferences for Pension Reform, August 2009

2771 Christian Breuer and Chang Woon Nam, VAT on Intra-Community Trade and Bilateral Micro Revenue Clearing in the EU, August 2009

2772 Choudhry Tanveer Shehzad, Jakob De Haan and Bert Scholtens, Growth and Earnings Persistence in Banking Firms: A Dynamic Panel Investigation, August 2009

2773 Erdal Yalcin, Uncertain Productivity Growth and the Choice between FDI and Export, August 2009

2774 Klaus Abberger, Wolfgang Nierhaus and Shynar Shaikh, Findings of the Signal Approach for Financial Monitoring in Kazakhstan, September 2009

2775 Sascha O. Becker, Francesco Cinnirella and Ludger Woessmann, The Trade-off between Fertility and Education: Evidence from before the Demographic Transition, September 2009

2776 Thomas Aronsson and Erkki Koskela, Optimal Income Taxation, Outsourcing and Policy Cooperation in a Dynamic Economy, September 2009

2777 Joel Slemrod, Old George Orwell Got it Backward: Some Thoughts on Behavioral Tax Economics, September 2009

2778 Cagri Seda Kumru and Athanasios C. Thanopoulos, Social Security Reform and Temptation, September 2009

2779 Alessandro Bucciol and Roel M. W. J. Beetsma, Inter- and Intra-generational Consequences of Pension Buffer Policy under Demographic, Financial and Economic Shocks, September 2009

2780 Eduardo Strube and Marcelo Resende, Complementarity of Innovation Policies in the Brazilian Industry: An Econometric Study, September 2009 
2781 Henry Tulkens and Vincent van Steenberghe, "Mitigation, Adaptation, Suffering": In Search of the Right Mix in the Face of Climate Change, September 2009

2782 Maria L. Loureiro, Anna Sanz-de-Galdeano and Daniela Vuri, Smoking Habits: Like Father, Like Son, Like Mother, Like Daughter, September 2009

2783 Momi Dahan, Tehila Kogut and Moshe Shalem, Do Economic Policymakers Practice what they Preach? The Case of Pension Decisions, September 2009

2784 Eytan Sheshinski, Uncertain Longevity and Investment in Education, September 2009

2785 Nannette Lindenberg and Frank Westermann, How Strong is the Case for Dollarization in Costa Rica? A Note on the Business Cycle Comovements with the United States, September 2009

2786 Leif Danziger, Noncompliance and the Effects of the Minimum Wage on Hours and Welfare in Competitive Labor Markets, September 2009

2787 Gerlinde Fellner, Rupert Sausgruber and Christian Traxler, Testing Enforcement Strategies in the Field: Legal Threat, Moral Appeal and Social Information, September 2009

2788 Gabriel J. Felbermayr, Mario Larch and Wolfgang Lechthaler, Unemployment in an Interdependent World, September 2009

2789 Sebastian G. Kessing, Federalism and Accountability with Distorted Election Choices, September 2009

2790 Daniel Gros, Global Welfare Implications of Carbon Border Taxes, September 2009

2791 Louis N. Christofides, Michael Hoy and Ling Yang, The Gender Imbalance in Participation in Canadian Universities (1977-2005), September 2009

2792 Jan K. Brueckner and Robert W. Helsley, Sprawl and Blight, September 2009

2793 Vidar Christiansen and Stephen Smith, Externality-correcting Taxes and Regulation, September 2009

2794 John Beirne, Guglielmo Maria Caporale, Marianne Schulze-Ghattas and Nicola Spagnolo, Global and Regional Spillovers in Emerging Stock Markets: A Multivariate GARCH-in-mean Analysis, September 2009

2795 Rüdiger Pethig and Frieder Kolleß, Asymmetric Capital-Tax Competition, Unemployment and Losses from Capital Market Integration, September 2009

2796 Ngo Van Long, Horst Raff and Frank Stähler, Innovation and Trade with Heterogeneous Firms, September 2009 